\title{
Thermal stability and inactivation of hepatitis $C$ virus grown in cell culture
}

\author{
Hongshuo Song ${ }^{1}$, Jin $\mathrm{Li}^{1}$, Shuang Shi', Ling Yan', Hui Zhuang ${ }^{1 *}, \mathrm{Kui} \mathrm{Li}^{\mathrm{i}^{*}}$
}

\begin{abstract}
Background: Hepatitis $\mathrm{C}$ virus ( $\mathrm{HCV}$ ) is a blood-borne flavivirus that infects many millions of people worldwide. Relatively little is known, however, concerning the stability of HCV and reliable procedures for inactivating this virus.

Methods: In the current study, the thermostability of cell culture-derived HCV (HCV CC, JFH-1 strain) under different environmental temperatures $\left(37^{\circ} \mathrm{C}\right.$, room temperature, and $\left.4^{\circ} \mathrm{C}\right)$ and the ability of heat, UVC light irradiation, and aldehyde and detergent treatments to inactivate $\mathrm{HCV}$ cc were evaluated. The infectious titers of treated viral samples were determined by focus-forming unit (FFU) assay using an indirect immunofluorescence assay for HCV NS3 in hepatoma Huh7-25-CD81 cells highly permissive for HCVCC infection. MTT cytotoxicity assay was performed to determine the concentrations of aldehydes or detergents at which they were no longer cytotoxic.

Results: $\mathrm{HCV} c \mathrm{C}$ in culture medium was found to survive $37^{\circ} \mathrm{C}$ and room temperature (RT, $25 \pm 2^{\circ} \mathrm{C}$ ) for 2 and 16 days, respectively, while the virus was relatively stable at $4^{\circ} \mathrm{C}$ without drastic loss of infectivity for at least 6 weeks. HCVCC in culture medium was sensitive to heat and could be inactivated in 8 and 4 min when incubated at $60^{\circ} \mathrm{C}$ and $65^{\circ} \mathrm{C}$, respectively. However, at $56^{\circ} \mathrm{C}, 40$ min were required to eliminate HCVcc infectivity. Addition of normal human serum to HCVcc did not significantly alter viral stability at RT or its susceptibility to heat. UVC light irradiation (wavelength $=253.7 \mathrm{~nm}$ ) with an intensity of $450 \mu \mathrm{W} / \mathrm{cm}^{2}$ efficiently inactivated HCVcc within 2 min. Exposures to formaldehyde, glutaraldehyde, ionic or nonionic detergents all destroyed HCVcc infectivity effectively, regardless of whether the treatments were conducted in the presence of cell culture medium or human serum.
\end{abstract}

Conclusions: The results provide quantitative evidence for the potential use of a variety of approaches for inactivating HCV. The ability of HCVcc to survive ambient temperatures warrants precautions in handling and disposing of objects and materials that may have been contaminated with HCV.

\section{Background}

Hepatitis $\mathrm{C}$ virus (HCV) is a small enveloped, positivestranded RNA virus classified within the family Flaviviridae, genus Hepacivirus. HCV affects an estimated 170 million people worldwide and is a global health problem. Unlike most RNA viruses which usually cause acute diseases, HCV establishes life-long, persistent, intrahepatic infections in a majority of infected individuals, leading frequently to the development of cirrhosis and hepatocellular carcinoma [1,2]. Because the current, interferon-based treatment regimens eradicate $\mathrm{HCV}$ in

\footnotetext{
* Correspondence: zhuangbmu@126.com; kli1@uthsc.edu

'Department of Microbiology, Peking University Health Science Center, Beijing 100191, China

${ }^{2}$ Department of Molecular Sciences, University of Tennessee Health Science Center, Memphis, Tennessee 38163, USA
}

only about $50 \%$ of patients, prevention of $\mathrm{HCV}$ infection is pivotal for controlling this viral pathogen.

$\mathrm{HCV}$ is transmitted primarily via percutaneous exposure to infectious blood. Prior to the introduction of anti-HCV screening tests in the early 1990s, receiving blood and blood products or organ transplants was a major risk factor for acquiring HCV infection. Currently, injection of illicit drugs represents a major risk, while other routes of infection, including occupational exposure (such as needle stick), sex, and mother-to-infant transmission (with the exception of HIV-coinfected mother), seem infrequent [3]. Interestingly, it was shown recently in the chimpanzee model that $\mathrm{HCV}$ in infectious plasma could survive drying and environmental exposure to room temperature for at least $16 \mathrm{~h}$. This finding has raised the possibility of person-to-person 
transmission of $\mathrm{HCV}$ via blood-contaminated objects and medical devices [4]. Clearly, it is fundamental to quantitatively determine the stability of $\mathrm{HCV}$ under environmental conditions and evaluate reliable procedures for inactivating this virus. However, such efforts have been hampered by the lack of an efficient cell culture system and convenient, small animal models for $\mathrm{HCV}$. Although HCV RNA and antigens have been used as indicators for the presence or absence of virus particles, such detection methods do not distinguish between the infectious and inactivated viruses [4-6]. To circumvent this, several related viruses in the family Flaviviridae that can be readily cultured in vitro, e.g., bovine viral diarrhoea virus (BVDV, genus Pestivirus), have been used as surrogates for HCV to study the inactivation process $[7,8]$. Although these model viruses show similarity in virion and genome structure to $\mathrm{HCV}$, more relevant systems are still needed to assess the reliable procedures for inactivating $\mathrm{HCV}$.

The recent establishment of an HCV cell culture system based on a particular molecular clone, JFH-1, offers the opportunity of evaluating the inactivation methods for HCV directly [9-12]. Using the Huh7-25-CD81 cell line that is highly susceptible to HCVcc infection [13], the stability of HCVCc (JFH-1 strain) at different environmental temperatures $\left(37^{\circ} \mathrm{C}\right.$, room temperature, and $4^{\circ}$ C) was assessed in this study. In addition, the efficacy of several commonly used viral inactivation methods, including heat treatment, UVC light irradiation, aldehyde-mediated fixation, and detergent treatments in eliminating $\mathrm{HCV} c \mathrm{c}$ infectivity were evaluated. The results revealed that all of these methods were able to inactivate $\mathrm{HCV} c \mathrm{c}$, provided proper conditions are met.

\section{Results}

\section{Stability of $\mathrm{HCVcc}$ at $37^{\circ} \mathrm{C}, \mathrm{RT}$, and $4^{\circ} \mathrm{C}$}

To investigate the ability of $\mathrm{HCV} \mathrm{Cc}$ to survive different environmental temperatures, the spontaneous reductions of viral titer at $37^{\circ} \mathrm{C}$, RT $\left(25 \pm 2^{\circ} \mathrm{C}\right)$, and $4^{\circ} \mathrm{C}$ were determined individually. The HCVcc stock $\left(2.5 \times 10^{4} \mathrm{FFU} / \mathrm{ml}\right.$ in culture medium) lost its infectivity after incubation at $37^{\circ} \mathrm{C}$ for $48 \mathrm{~h}$, when the FFU assay became negative and no residual infectivity was found upon three successive passages of the inoculated Huh7-25-CD81 cultures (Figure 1A). Most of the infectivity loss occurred within the first $24 \mathrm{~h}$ [from $2.5 \times 10^{4} \mathrm{FFU} / \mathrm{ml}$ to $(5.7 \pm 0.6) \times 10^{1}$ $\mathrm{FFU} / \mathrm{ml}$, a $2.6-\log$ reduction], while a further $0.4-\log$ reduction in the following $16 \mathrm{~h}$ brought the virus titer down to $(2.3 \pm 0.6) \times 10^{1} \mathrm{FFU} / \mathrm{ml}$, close to the detection limit $(10 \mathrm{FFU} / \mathrm{ml})$. In contrast to $37^{\circ} \mathrm{C}$, viral titers declined much more slowly and smoothly at RT (Figure 1B). Incubation for every 2 days led to $0.4-$ to $0.5-\log$ reduction in viral titers until day 14 when infectivity dropped to the level of detection limit. The virus stock became completely devoid of infectivity at day 16 (Figure 1B) and later (data not shown). When incubated at $4^{\circ} \mathrm{C}$, no obvious loss of viral infectivity was detected within the first 4 weeks (Figure 1C). However, we noticed a nearly $0.5-\log$ reduction of viral titer after 6 weeks, when the experiments were ended. Lindenbach et al reported that the infectivity of J6/JFH1 HCVCc did not change after three freeze-thaw cycles [10]. Consistent with this, we found no obvious reduction of infectivity even after five cycles of freezing and thawing of the JFH1 HCVcc stock (data not shown). This suggests that $\mathrm{HCV} c \mathrm{c}$ is relatively insensitive to freeze-thaw manipulation.

To determine whether the presence of human blood affects the stability of HCVcc, a concentrated HCVcc stock was diluted in normal human serum to achieve a titer of $1.0 \times 10^{5} \mathrm{FFU} / \mathrm{ml}$. At RT, this HCVcc-containing serum was found to gradually loose its infectivity in 3 weeks, with 1.4- to 1.7- log reduction in viral titer after every week of incubation (Figure 1D). However, when the HCVcc diluted in human serum $\left(1.0 \times 10^{5} \mathrm{FFU} / \mathrm{ml}\right)$ was dried on the surface of cell culture dishes and incubated at RT for 1 week, no infectivity was detected upon inoculation of the reconstituted serum onto naïve Huh7-25-CD81 cells even after three consecutive cell passages (data not shown). In aggregate, these results suggest that HCVcc is able to survive ambient conditions especially in a liquid environment, and that stability of $\mathrm{HCVcc}$ is inversely correlated with temperature.

\section{Effect of heat treatment on HCVcc infectivity}

To evaluate the sensitivity of $\mathrm{HCVcc}$ to heat treatment, aliquots of HCVcc stock $\left(2.5 \times 10^{4} \mathrm{FFU} / \mathrm{ml}\right)$ were treated with three increasing temperatures $\left(56^{\circ} \mathrm{C}, 60^{\circ} \mathrm{C}\right.$, and $65^{\circ} \mathrm{C}$, respectively). As shown in Figure $2 \mathrm{~A}$, at $56^{\circ} \mathrm{C}$ $\mathrm{HCV}$ cc lost most of its infectivity within $30 \mathrm{~min}$, with a 2.9- $\log$ reduction in viral titer [from $2.5 \times 10^{4} \mathrm{FFU} / \mathrm{ml}$ to $\left.(3.3 \pm 0.6) \times 10^{1} \mathrm{FFU} / \mathrm{ml}\right)$. However, after $35 \mathrm{~min}$, a very small amount of infectious virus was still detectable $\left[(1.3 \pm 0.6) \times 10^{1} \mathrm{FFU} / \mathrm{ml}\right]$. Complete viral inactivation took place at $40 \mathrm{~min}$ (Figure 2A), and no residual infectivity was detected for samples treated beyond this time point (data not shown). Heat treatments at higher temperatures led to a more rapid decline in viral titer. At $60^{\circ} \mathrm{C}$ or $65^{\circ} \mathrm{C}$ (Figure 2B), HCV stocks were inactivated completely by 8 or 4 min, respectively.

Similar kinetics of viral inactivation was observed when heat treatment was performed on HCVcc stocks spiked in human serum. When incubated at $56^{\circ} \mathrm{C}$, the viral titer dropped by $3.6-\log$ in the first $30 \mathrm{~min}$ [from $1.0 \times 10^{5} \mathrm{FFU} / \mathrm{ml}$ to $\left.(3.3 \pm 0.6) \times 10^{1} \mathrm{FFU} / \mathrm{ml}\right]$. By 40 min viral infectivity could be no longer detected (Figure $1 \mathrm{C}$ ). At $60^{\circ} \mathrm{C}$ and $65^{\circ} \mathrm{C}$, the $\mathrm{HCVcc}$-containing serum was completely inactivated by 10 and $4 \mathrm{~min}$, respectively 


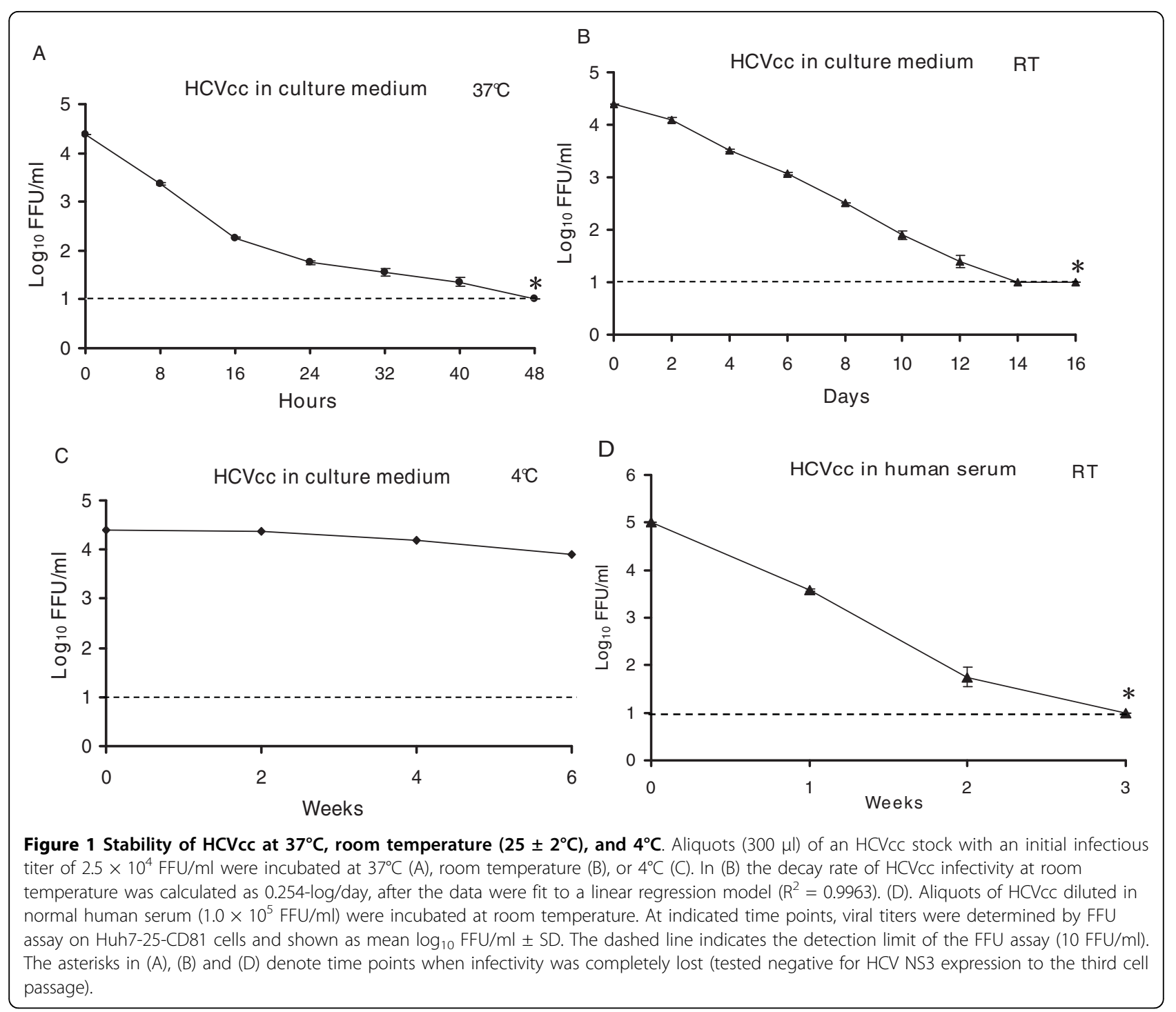

(Figure 2D). Taken together, these results indicate that $\mathrm{HCVCC}$ is sensitive to heat treatment and $56^{\circ} \mathrm{C}$ or higher temperatures could be used for effective $\mathrm{HCV}$ cc inactivation. Of note, the presence of human serum does not seem to affect the susceptibility of HCVcc to heat treatment.

\section{Effect of UVC light irradiation on HCVcc infectivity}

To examine the effect of continuous UVC light on HCVcc infectivity, 200- $\mu \mathrm{l}$ aliquots of HCVcc stock $\left(2.5 \times 10^{4} \mathrm{FFU} / \mathrm{ml}\right)$ were placed in 48 -well plates and subjected to UVC light irradiation for different time points, and the residual titers were determined immediately. As shown in Figure 3A, viral titers declined rapidly following UVC irradiation, by 1.4- and 2.4-log, in the first 15 and $30 \mathrm{sec}$ of exposure, respectively. After $45 \mathrm{sec}$, the viral titer decreased to a level $[(2.7 \pm 1.2) \times$
$10^{1} \mathrm{FFU} / \mathrm{ml}$ ] close to the detection limit of the FFU assay. HCVcc infectivity was eliminated completely after 1 min of irradiation. In contrast, the control, nonirradiated samples incubated at RT for 1 min showed no loss in titer (data not shown).

The effect of UVC light on the infectivity of HCVcc spiked in human serum was also investigated. As shown in Figure 3B, an 1.6-log decrease in viral infectivity was observed after the first $30 \mathrm{sec}$ of irradiation [from $1.0 \times$ $10^{5} \mathrm{FFU} / \mathrm{ml}$ to $\left.\left.(2.6 \pm 0.5) \times 10^{3} \mathrm{FFU} / \mathrm{ml}\right)\right]$. Exposure to UVC light for $90 \mathrm{sec}$ brought the viral titer down to a level that was close to the limit of detection, while an additional 30-sec exposure (a total of $120 \mathrm{sec}$ ) completely eliminated the residual infectivity (Figure 3B). Given that the radiant intensity at a distance of $30 \mathrm{~cm}$ from the UVC lamp was $450 \mu \mathrm{W} / \mathrm{cm}^{2}$ (where $\mu \mathrm{W}=10^{-6} \mathrm{~J} / \mathrm{sec}$ ), these data suggest that continuous UVC light at a 

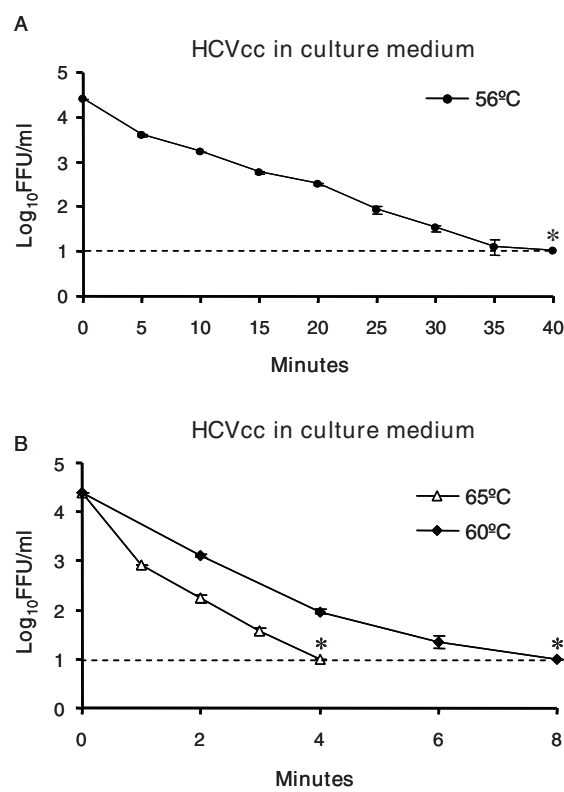

C

HCVcc in human serum

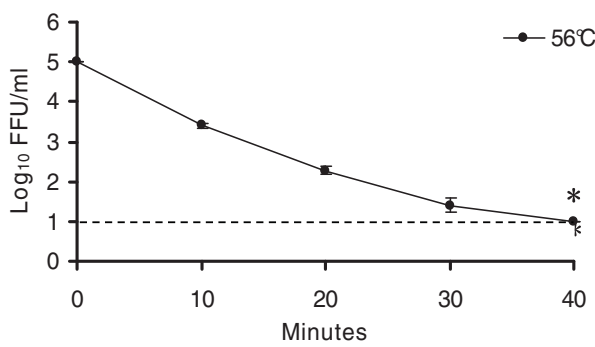

D

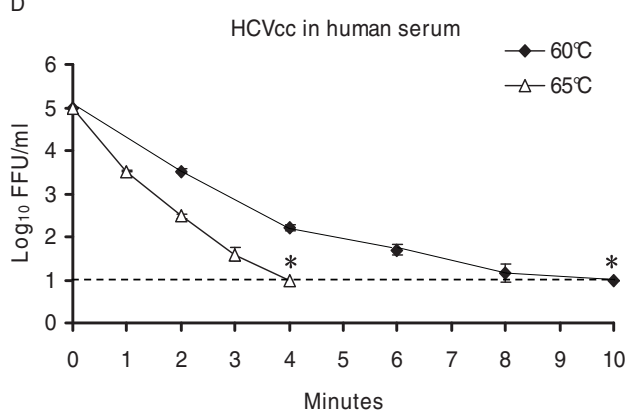

Figure 2 Inactivation of HCVcc by heat treatment. Aliquots (100 $\mu \mathrm{ll})$ of an HCVcc virus stock $\left(2.5 \times 10^{4} \mathrm{FFU} / \mathrm{ml}\right)$ or HCVcc diluted in normal human serum $\left(1.0 \times 10^{5} \mathrm{FFU} / \mathrm{ml}\right)$ were incubated in water baths at $56^{\circ} \mathrm{C}(\mathrm{A}$ and $\mathrm{C}), 60^{\circ} \mathrm{C}$ and $65^{\circ} \mathrm{C}(\mathrm{B}$ and $\mathrm{D})$. At indicated time points post incubation, samples were removed, cooled on ice-water bath, and their residual infectivity titrated on Huh7-25-CD81 cells. The dashed line indicates the detection limit of the FFU assay (10 $\mathrm{FFU} / \mathrm{ml}$ ). The asterisks denote time points when infectivity was eliminated completely (tested negative in FFU assay and remained negative for HCV NS3 expression to the third cell passage). The decay rate of $\mathrm{HCV} c \mathrm{c}$ infectivity at $56^{\circ} \mathrm{C}$ was calculated as $0.089-\mathrm{log} /$ min and $0.119-\mathrm{log} / \mathrm{min}$, for HCVcc in culture medium (A) and human serum $(C)$, respectively, after the data were fit to a linear regression model $\left(R^{2}=0.9883\right.$ and 0.9813 , respectively). radiation dose of $5.4 \times 10^{-2} \mathrm{~J} / \mathrm{cm}^{2}(\mathrm{t}=120 \mathrm{sec})$ is sufficient to inactivate HCVcc with a titer of $1.0 \times 10^{5} \mathrm{FFU} / \mathrm{ml}$.

\section{Effects of formaldehyde and glutaraldehyde treatments on HCVcc infectivity}

MTT assay was first carried out to determine the aldehyde concentrations at which they no longer affected cell viability. It was found that $0.00037 \%$ formaldehyde and $0.0001 \%$ glutaraldehyde no longer had a demonstrable effect on cell growth/viability (Figure 4A). Also, at these aldehyde concentrations, the viral titration results were not perturbed (Table 1 and 2). Therefore, viral samples treated with $0.037 \%$ formaldehyde or $0.01 \%$ glutaraldehyde were diluted 100 -fold for infectivity assay. The reduction in viral titer of an $\mathrm{HCV} c \mathrm{c}$ stock $\left(4.1 \times 10^{4} \mathrm{FFU} / \mathrm{ml}\right)$ following exposure to each of the aldehydes is summarized in Table 1 . At $2 \mathrm{~h}$ posttreatment of formaldehyde, a single fluorescent focus was detected in one of the triplicate wells in the FFU assay, while the other two wells showed negative results. Virus samples treated for $2.5 \mathrm{~h}$ were negative in the FFU assay; however, a positive IFA result was observed at the second cell passage, indicating the presence of residual infectious virus. After $3 \mathrm{~h}$ of treatment, no residual infectivity could be detected up to the third cell passage (Table 1). Compared with $0.037 \%$ formaldehyde, $0.01 \%$ glutaraldehyde exhibited a higher efficacy in viral inactivation. Ten minutes of glutaraldehyde treatment resulted in more than 1-log reduction in infectivity. After $20 \mathrm{~min}$, the virus stock was inactivated completely, with no residual infectivity being detected up to the third cell passage (Table 1).

The effect of aldehydes on the infectivity of $\mathrm{HCV} c \mathrm{c}$ in human serum $\left(1.0 \times 10^{5} \mathrm{FFU} / \mathrm{ml}\right)$ was also evaluated by using the same procedure as described above. As shown in Table 2, 3 hours of incubation in $0.037 \%$ formaldehyde decreased the viral titer to the limit of detection $\left[(1.0 \pm 0.0) \times 10^{3} \mathrm{FFU} / \mathrm{ml}\right.$, a 2-log drop]. After 4 hours, no residual infectivity could be detected (Table 2). In agreement with the results for $\mathrm{HCV} c \mathrm{c}$ in culture medium, $0.01 \%$ glutaraldehyde was also more effective than $0.037 \%$ formaldehyde in inactivation of $\mathrm{HCVcc}$ in human serum. The results of FFU assay became negative after treatment with $0.01 \%$ glutaraldehyde for $30 \mathrm{~min}$, although a small amount of infectious virus was detectable at the second cell passage, By $40 \mathrm{~min}$, no residual infectivity could be detected up to the third cell passage, indicating that effective viral inactivation was achieved (Table 2). In all experiments, the control, PBS-treated samples showed no obvious loss of infectivity when titrated in the presence of $0.00037 \%$ formaldehyde or $0.0001 \%$ glutaraldehyde (data not shown). These results suggest that both of the aldehydes are able to inactivate HCVcc, regardless of the presence of human serum in 
A

HCVcc in culture medium

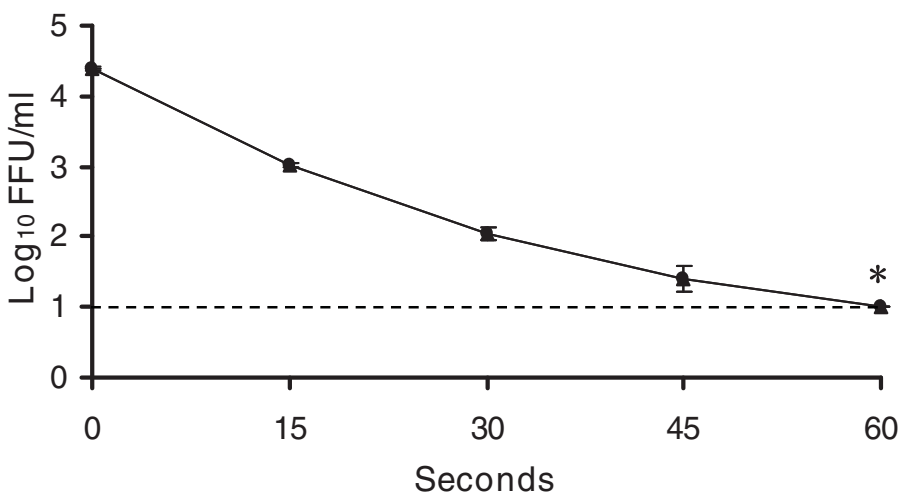

B

HCVcc in human serum

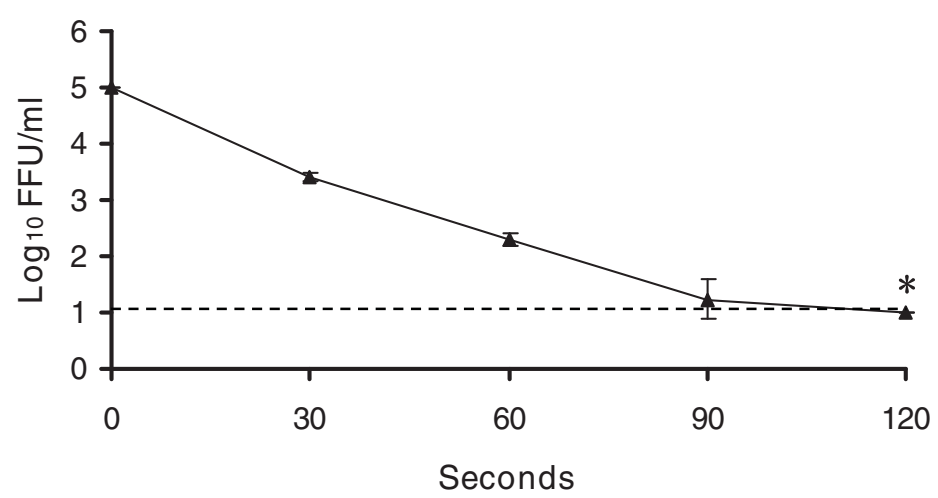

Figure 3 Inactivation of the HCVcc by UVC light irradiation. Aliquots (200 $\mu$ l) of an HCVcc stock (A) or normal human serum containing HCVCC (B) were placed $30 \mathrm{~cm}$ beneath the longitudinal midpoint of a UVC lamp. Samples were removed at indicated time points, and viral titers were determined on Huh7-25-CD81 cells immediately. The dashed line indicates the detection limit of the FFU assay (10 FFU/ml). The asterisk denotes the time point when infectivity was completely lost (tested negative in FFU assay and remained negative for HCV NS3 expression to the third cell passage). The decay rate of HCVCC infectivity after UVC light irradiation was calculated as 0.067-log/sec and 0.041-log/ sec, for HCVcc in culture medium (A) and human serum (B), respectively, after the data were fit to a linear regression model $\left(R^{2}=0.9738\right.$ and 0.9891, respectively).

HCVcc stocks, and that glutaraldehyde is more effective than is formaldehyde.

\section{Effects of detergent treatments on HCVcc infectivity}

To determine the detergent concentrations at which they were no longer cytotoxic to cells, Huh7-25-CD81 cells were treated with individual, serially diluted detergents and subjected to MTT assay to assess cell viability. Based on the MTT assay results (Figure 4B and $4 \mathrm{C}$ ), HCVcc stocks $\left(4.1 \times 10^{4} \mathrm{FFU} / \mathrm{ml}\right)$ or those spiked in human serum $\left(1.0 \times 10^{5} \mathrm{FFU} / \mathrm{ml}\right)$ were treated with $0.1 \%$ SDS, $0.2 \%$ Triton X-100, or $0.2 \%$ NP-40, and then tested for infectivity at either 100-fold (SDS-treated samples) or 400-fold (Triton X-100- or NP-40-treated samples) dilution. As summarized in Table 3 , all of the detergent-treated samples were negative in the FFU assay and demonstrated no residual infectivity upon three consecutive passages of the inoculated cells (Table 3). In contrast, control samples not treated with detergents showed no obvious loss in virus titers.

The effect of detergents on disrupting intracellular HCVcc virions was also evaluated. JFH-1-infected Huh7-25-CD81 cultures (with 100\% cells positive for NS3 as determined by immunofluorescence assay) were lysed in each of the detergent solutions (0.1\% SDS, $0.2 \%$ Triton X-100, or $0.2 \%$ NP-40 in PBS, respectively), and the clarified supernatants were tested for infectivity on naïve Huh7-25-CD81 cells at 100-fold (SDS-lysed samples) or 400-fold (Triton X-100- or NP-40-lysed samples) dilution, respectively. No infectivity was detected 


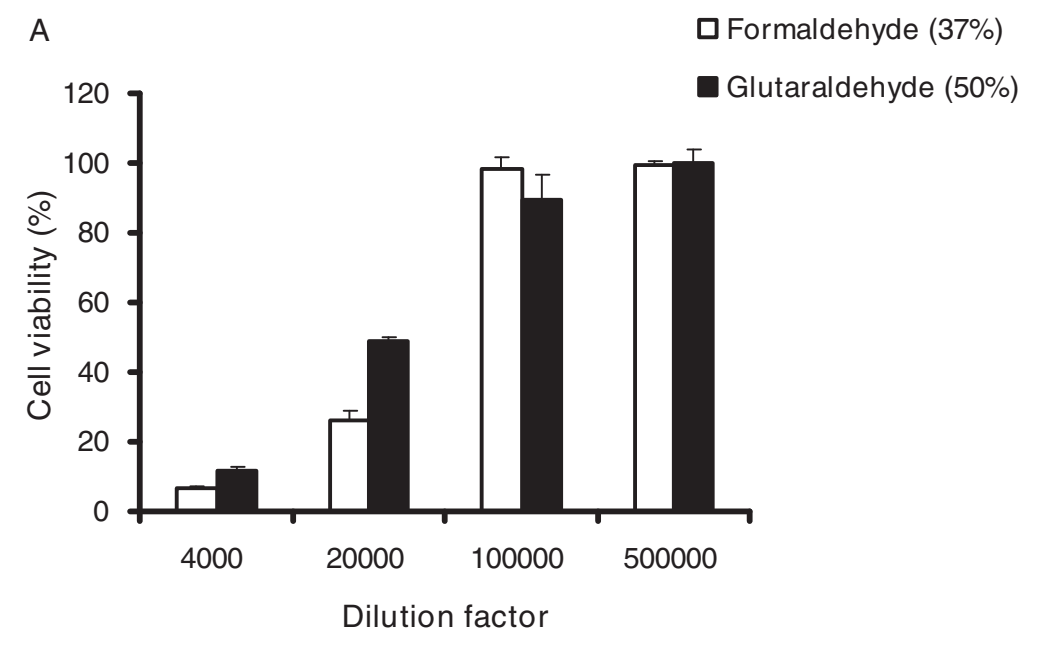

B
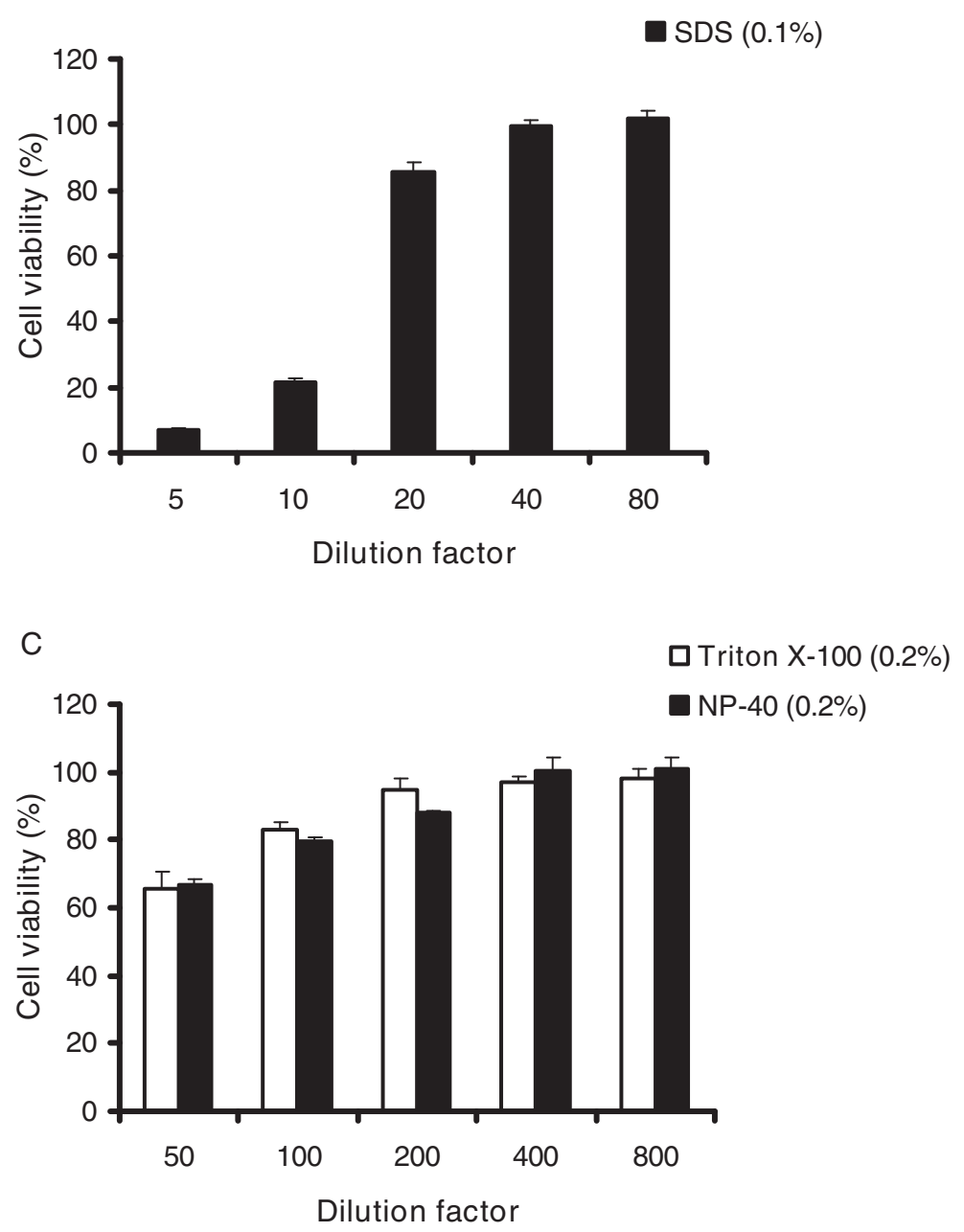

Figure 4 MTT assay of cytotoxicity associated with various concentrations of aldehydes or detergents. Solutions of formaldehyde $(37 \%$ or glutaraldehyde (50\%) (A), SDS (0.1\%) (B), and Triton X-100 (0.2\%) or NP-40 (0.2\%) (C) were diluted serially in cell culture medium by dilution factors indicated in the X-axes, then added to Huh7-25-CD81 cells seeded in 96-well plates. The treated cells were refed with $100 \mu$ l of fresh medium after $6 \mathrm{~h}$ of incubation. MTT assay was carried out after an additional $72 \mathrm{~h}$ as described in Methods. Data are presented as the percentage of cell viability relative to the untreated controls (mean $\pm S D, n=3$ ). 
Table 1 Effects of formaldehyde and glutaraldehyde on infectivity of HCVCc in culture medium

\begin{tabular}{|c|c|c|c|}
\hline \multirow[t]{2}{*}{ Treatment } & \multirow{2}{*}{$\begin{array}{l}\text { Infectious titer } \\
\text { (FFU/ml) }\end{array}$} & \multicolumn{2}{|c|}{ IFA result } \\
\hline & & $2^{\text {nd }}$ cell passage & $3^{\text {rd }}$ cell passage \\
\hline \multicolumn{4}{|c|}{ Formaldehyde $(0.037 \%)$} \\
\hline $\mathrm{Oh}$ & $(3.9 \pm 0.3) \times 10^{4 a}$ & $N T^{c}$ & NT \\
\hline $0.5 \mathrm{~h}$ & $(1.1 \pm 0.1) \times 10^{4}$ & NT & NT \\
\hline $1.0 \mathrm{~h}$ & $(4.0 \pm 1.0) \times 10^{3}$ & NT & NT \\
\hline $1.5 \mathrm{~h}$ & $(1.7 \pm 0.6) \times 10^{3}$ & NT & NT \\
\hline $2.0 \mathrm{~h}$ & $\leq 1.0 \times 10^{3 \mathrm{~b}}$ & positive & NT \\
\hline $2.5 \mathrm{~h}$ & $<1.0 \times 10^{3}$ & positive & NT \\
\hline $3.0 \mathrm{~h}$ & $<1.0 \times 10^{3}$ & negative & negative \\
\hline \multicolumn{4}{|c|}{ Glutaraldehyde $(0.01 \%)$} \\
\hline $0 \min$ & $(4.0 \pm 0.3) \times 10^{4 a}$ & NT & NT \\
\hline $10 \mathrm{~min}$ & $(3.3 \pm 0.6) \times 10^{3}$ & NT & NT \\
\hline $20 \mathrm{~min}$ & $<1.0 \times 10^{3}$ & negative & negative \\
\hline
\end{tabular}

${ }^{a}$ Untreated viral samples were retitrated in culture medium containing $0.00037 \%$ formaldehyde or $0.0001 \%$ glutaraldehyde as controls.

${ }^{\mathrm{b}}$ One focus was detected in one of the triplicate wells in FFU assay.

${ }^{c} \mathrm{NT}$, not tested. Samples with positive results in FFU assay or at the second cell passage were not tested for NS3 staining for the third cell passage.

from any of these cell lysates in three consecutive passages of inoculated cells (Table 3), while the control cell lysate prepared by freezing and thawing in the absence of any detergents retained high infectivity (Table 3). Taken collectively, these results suggest that each of the detergents, at the tested concentration, is highly effective in eliminating the infectivity of both extracellular and intracellular HCVcc particles.

\section{Discussion}

In this study, a detailed analysis was conducted on the stability of $\mathrm{HCVCc}$ at various environmental temperatures. Also evaluated was the efficacy of several conventional viral inactivation procedures in eliminating HCVcc infectivity.

It has been shown previously that genotype $1 \mathrm{a} \mathrm{HCV}$ in infectious plasma could survive drying and environmental exposure to RT for at least $16 \mathrm{~h}$ [4]. The results of the current study have demonstrated that JFH-1 virus (genotype 2a) grown in cell culture can survive $37^{\circ} \mathrm{C}$ and RT for 2 and 16 days, respectively (Figure 1A and 1B). Of note, the stability of JFH1 HCVcc spiked in human serum did not differ much from those in cell culture medium when incubated at RT (Fig. 1D). When stored at $4^{\circ} \mathrm{C}, \mathrm{JFH}-1$ virus was found to be relatively stable, without drastic loss of titer during the 6-week observation period (Figure 1C). The latter result is in agreement with a previous report dealing with the J6/ JFH1 chimeric virus [10]. The ability of HCVcc to survive various environmental temperatures warrants precautions in handling and disposing objects and materials
Table 2 Effects of formaldehyde and glutaraldehyde on infectivity of HCVCc in human serum

\begin{tabular}{|c|c|c|c|}
\hline \multirow[t]{2}{*}{ Treatment } & \multirow{2}{*}{$\begin{array}{l}\text { Infectious titer } \\
\text { (FFU/ml) }\end{array}$} & \multicolumn{2}{|c|}{ IFA result } \\
\hline & & $2^{\text {nd }}$ cell passage & $3^{\text {rd }}$ cell passage \\
\hline \multicolumn{4}{|c|}{ Formaldehyde (0.037\%) } \\
\hline $\mathrm{Oh}$ & $(8.5 \pm 0.7) \times 10^{4 a}$ & $N T^{b}$ & NT \\
\hline $1.0 \mathrm{~h}$ & $(1.9 \pm 0.4) \times 10^{4}$ & NT & NT \\
\hline $2.0 \mathrm{~h}$ & $(3.5 \pm 0.7) \times 10^{3}$ & NT & NT \\
\hline $3.0 \mathrm{~h}$ & $(1.0 \pm 0.0) \times 10^{3}$ & NT & NT \\
\hline $4.0 \mathrm{~h}$ & $<1.0 \times 10^{3}$ & negative & negative \\
\hline \multicolumn{4}{|c|}{ Glutaraldehyde (0.01\%) } \\
\hline $0 \mathrm{~min}$ & $(9.5 \pm 0.7) \times 10^{4 a}$ & NT & NT \\
\hline $10 \mathrm{~min}$ & $(1.8 \pm 0.2) \times 10^{4}$ & NT & NT \\
\hline $20 \mathrm{~min}$ & $(2.5 \pm 0.7) \times 10^{3}$ & NT & NT \\
\hline $30 \mathrm{~min}$ & $<1.0 \times 10^{3}$ & Positive & NT \\
\hline $40 \mathrm{~min}$ & $<1.0 \times 10^{3}$ & negative & negative \\
\hline
\end{tabular}

${ }^{a}$ Untreated viral samples were retitrated in culture medium containing $0.00037 \%$ formaldehyde or $0.0001 \%$ glutaraldehyde as controls.

${ }^{b}$ NT, not tested. Samples with positive results in FFU assay or at the second cell passage were not tested for NS3 staining for the third cell passage.

that may have been contaminated with $\mathrm{HCV}$, to minimize the risk of $\mathrm{HCV}$ transmission.

Heat treatment is a widely used viral inactivation method that is effective against both enveloped and nonenveloped viruses [14]. The mechanisms of heatmediated inactivation include denaturation of viral proteins, as well as disassembly of virus particles into noninfectious viral subunits and single proteins [15]. Viruses other than $\mathrm{HCV}$ in the family Flaviviridae have been shown to be sensitive to heat treatment. Yellow fever virus is routinely inactivated at $56^{\circ} \mathrm{C}$ for $30 \mathrm{~min}$. At $60^{\circ}$ $\mathrm{C}, \mathrm{BVDV}$ and yellow fever virus have been reported to be inactivated effectively in 30 and $5 \mathrm{~min}$, respectively $[8,16]$. In the current study, similar kinetics of viral inactivation following heat treatment was observed for both the HCVcc in culture medium and those in human serum. While $10 \mathrm{~min}$ at $60^{\circ} \mathrm{C}$ or $4 \mathrm{~min}$ at $65^{\circ} \mathrm{C}$ was sufficient to eliminate the infectivity of $\mathrm{HCVcc}$, incubation for $40 \mathrm{~min}$ was required to achieve complete viral inactivation at $56^{\circ} \mathrm{C}$ (Figure 2). Therefore, pretreatment of $\mathrm{HCV}$ positive sera for $30 \mathrm{~min}$ at $56^{\circ} \mathrm{C}$ may not be absolutely reliable in eliminating their infectivity. However, because the efficiency of heat treatment could be affected by a variety of factors, such as the initial viral titer, protein concentration in virus suspension, as well as the existence of viral aggregates $[8,17]$ the exact temperature and time required for reliable $\mathrm{HCV}$ inactivation should be evaluated under each specific condition.

UV light irradiation is another commonly used physical method for viral inactivation. UVC with a wavelength range of 200-280 $\mathrm{nm}$ prevents viral replication by inducing formation of pyrimidine dimers in the viral 
Table 3 Effects of detergent treatments on HCVcc infectivity

\begin{tabular}{|c|c|c|c|}
\hline Treatment & Infectious titers before treatment $(\mathrm{FFU} / \mathrm{ml})^{\mathrm{a}}$ & FFU assay after treatment & IFA result at the $3^{\text {rd }}$ cell passage \\
\hline \multicolumn{4}{|l|}{$0.1 \%$ SDS } \\
\hline HCVcc in culture medium & $(4.1 \pm 0.2) \times 10^{4}$ & negative & negative \\
\hline HCVcc in human serum & $(9.5 \pm 0.7) \times 10^{4}$ & negative & negative \\
\hline cell lysates & $(5.5 \pm 0.1) \times 10^{5}$ & negative & negative \\
\hline \multicolumn{4}{|l|}{$0.2 \%$ Triton $\mathrm{X}-100$} \\
\hline HCVcc in culture medium & $(2.0 \pm 0.2) \times 10^{4}$ & negative & negative \\
\hline HCVcc in human serum & $(6.0 \pm 0.0) \times 10^{4}$ & negative & negative \\
\hline cell lysate & $(3.1 \pm 0.2) \times 10^{5}$ & negative & negative \\
\hline \multicolumn{4}{|l|}{$0.2 \% \mathrm{NP}-40$} \\
\hline HCVcc in culture medium & $(1.6 \pm 0.2) \times 10^{4}$ & negative & negative \\
\hline HCVcc in human serum & $(5.5 \pm 0.2) \times 10^{4}$ & negative & negative \\
\hline cell lysate & $(2.9 \pm 0.2) \times 10^{5}$ & negative & negative \\
\hline
\end{tabular}

${ }^{a}$ Untreated viral samples or intracellular viral infectivity in untreated, HCVcc-infected cell lysates prepared by freeze-and-thaw were retitrated in the presence of $0.001 \%$ SDS, $0.0005 \%$ Triton X-100 or $0.0005 \%$ NP-40, respectively, to keep in line with the final concentration of the detergents in the treated samples during titration.

genome [18]. A recent study reported that BVDV, when suspended in PBS, could be inactivated completely by $1.6 \mathrm{~J} / \mathrm{cm}^{2}$ UVC light, while viral suspension containing $5 \%$ FBS required a higher radiation dose [7]. The current study demonstrated that $\mathrm{HCVcc}$ in culture medium $\left(2.5 \times 10^{4} \mathrm{FFU} / \mathrm{ml}\right.$, volume depth of $\left.0.2 \mathrm{~cm}\right)$ could be inactivated completely by UVC irradiation at a dose of $2.7 \times 10^{-2} \mathrm{~J} / \mathrm{cm}^{2}$ within $1 \mathrm{~min}$ (Figure $3 \mathrm{~A}$ ), while those spiked in human serum $\left(1.0 \times 10^{5} \mathrm{FFU} / \mathrm{ml}\right)$ required an irradiation dose of $5.4 \times 10^{-2} \mathrm{~J} / \mathrm{cm}^{2}$ for full inactivation (Figure 3B). Therefore, UVC light irradiation represents a highly effective means for inactivating HCVcc, the efficiency of which is not affected by human serum components that may interact with $\mathrm{HCV}$ virons in vivo. However, the irradiation dose required for each specific occasion may depend on the sample volume and its initial viral titer.

As a chemical cross-linking reagent, formaldehyde inactivates viruses primarily by denaturing viral proteins, as well as the nucleic acids $[19,20]$. Because the immunogenicity of the viral particles can be retained during inactivation, formalin ( $37 \%$ formaldehyde) treatment is the most used technique for preparing inactivated virus vaccines. For tissue fixation for histology or immunohistochemistry, $10 \%$ formalin (or $4 \%$ paraformaldehyde) is routinely used. Glutaraldehyde is another effective protein cross-linking reagent, mostly used for fixation of tissues for electron microscopy. Although the detailed mechanisms are not entirely clear yet, successful inactivation of many viruses with glutaraldehyde, including hepatitis B virus, human immunodeficiency virus (HIV), and SARS coronavirus, has been reported [18,21,22]. We demonstrated here that at RT, $3 \mathrm{~h}$ of exposure to formaldehyde $(0.037 \%)$ or $20 \mathrm{~min}$ of exposure to glutaraldehyde $(0.01 \%)$, respectively, could reduce HCVcc infectivity from $4.1 \times 10^{4} \mathrm{FFU} / \mathrm{ml}$ to undetectable levels
(Table 1). At these concentrations both aldehydes were also effective in inactivating $\mathrm{HCVcc}$ in the presence of human serum (Table 2). The slightly longer times required ( $4 \mathrm{~h}$ for formaldehyde treated samples and 40 min for glutaraldehyde treated samples, respectively) were most likely attributed to the 2.5 -fold higher initial titer of the HCVCc stock tested $\left(1.0 \times 10^{5} \mathrm{FFU} / \mathrm{ml}\right)$. However, a limitation of the current study is that, because of the cytotoxic effect of the aldehydes, the infectivity of viral samples could be analyzed at only the 100-fold dilution, which may somehow have reduced the sensitivity of the assay. It should be noted, however, the routinely used concentrations of aldehydes for fixation purposes ( $4 \%$ for formaldehyde and $2.5 \%$ for glutaraldehyde) are far in excess of the ones examined in the current study and, therefore, should be highly efficient in achieving $\mathrm{HCV}$ inactivation.

Detergents are highly efficient at disrupting the lipidenveloped viruses, and solvent/detergent (S/D) treatment is a standard method for inactivating viruses present in human blood products [22]. The effects of both ionic (SDS) and nonionic (Triton X-100 and NP-40) detergents on $\mathrm{HCVcc}$ infectivity have been investigated here. All three detergents at the tested concentrations reduced $\mathrm{HCV} c \mathrm{c}$ infectivity rapidly to undetectable levels (Table 3). Importantly, both intracellular HCVcc and those released into culture fluid could be inactivated by each of these detergents, regardless of the presence of human serum, indicating that components of culture medium, human serum or intracellular proteins did not interfere with the disruptive processes exerted by these detergents. Under current experimental conditions, effective $\mathrm{HCVCc}$ inactivation took place immediately after vortex-mixing, rendering it impossible to delineate the kinetics of viral infectivity reduction during the detergent treatment process. This finding is reminiscent 
of that reported for HIV in a previous study, which demonstrated that HIV-1 spiked in solution containing 1\% Triton X-100 was inactivated completely within 1 min [23]. As in the case of the aldehyde-inactivation experiments, the cytotoxic effect of detergents limited the sensitivity of the current assays. Interestingly, although $0.0005 \%$ Triton X-100 and $0.0005 \%$ NP-40 had no detectable effect on cell viability (Figure $4 \mathrm{C}$ ), they still lowered HCVcc infectivity by 1.7 - to 2.5 -fold when the latter was compared with those determined in the presence of $0.001 \%$ SDS or without any detergent (Table 3). Most likely, the residual Triton X-100 or NP-40 still had some disruptive effect on virion integrity, which is important for viral infectivity. Alternatively, these detergents may have caused some cell surface alterations at this extremely low concentration that affect the process of HCVcc entry. However, to maintain the sensitivity of the assay, the detergent-treated samples were not diluted further for the infectivity test. Collectively, the robustness and immediate action of detergents in destroying HCVcc infectivity support the use of S/D treatment procedures in eliminating potential $\mathrm{HCV}$ contaminations in blood products.

\section{Conclusions}

In summary, results presented in the current study revealed the stability of $\mathrm{HCVcc}$ (genotype 2a, JFH-1 strain) under different temperatures and provided quantitative evidence that heat, UVC light irradiation, aldehyde (formaldehyde and glutaraldehyde), and detergent treatments all can be used as effective means for inactivating HCVcc. However, because the stability and resistance of $\mathrm{HCV}$ to different inactivation methods may vary from genotype to genotype, and even strain to strain, the optimal method and procedure used for $\mathrm{HCV}$ inactivation should be verified under each particular circumstance. We also note that the results of the current study were developed using an in vitro cell culture system based on hepatoma Huh7 cells, which may differ from normal human hepatocytes in supporting HCV infection. Thus, to what extent the procedures described herein can be applied to an in vivo setting awaits further evaluation.

\section{Methods}

\section{Cell culture and virus stocks}

The Huh7-25-CD81 cell line (a generous gift from Dr. Takaji Wakita), a Huh7 cell clone that stably expresses human CD81 [13], was used throughout the experiments. This cell line was chosen because we found it was approximately 1.5 - to 2 -fold more sensitive for titration of HCVcc infectivity than was the Huh7.5.1 cell line (data not shown). Cells were maintained in DMEM supplemented with $10 \%$ fetal bovine serum (Invitrogen), 10

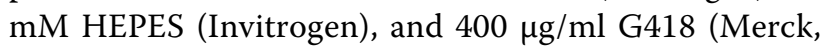

Germany) at $37^{\circ} \mathrm{C}$ in $5 \% \mathrm{CO}_{2}$. To generate JFH-1 virus stocks, cell culture supernatant collected from fulllength JFH-1 RNA-transfected Huh7 cells (kindly provided by Dr. Takaji Wakita) was used to infect Huh725-CD81 cells grown in T25 flasks at a multiplicity of infection (MOI) of 0.01. The infected cells were passaged at 3-day intervals with 1:3 to 1:4 split ratios into progressively larger culture vessels. At 12 days postinfection, the culture supernatants were harvested, clarified by centrifugation ( $5 \mathrm{~min}$ at $4000 \mathrm{rpm}$ ), and stored in aliquots at $-70^{\circ} \mathrm{C}$ as the $\mathrm{HCV} c \mathrm{c}$ stock. The infectious titer of the virus stock was determined by focus-forming unit (FFU) assay as described immediately below (the infectious titers of the un-concentrated virus stocks used were either $2.5 \times 10^{4} \mathrm{FFU} / \mathrm{ml}$ or $4.1 \times 10^{4} \mathrm{FFU} / \mathrm{ml}$ in the current study, as specified in each experiment).

To determine the stability of $\mathrm{HCVcc}$ and its susceptibility to individual inactivation methods in the presence of human serum, a condition which better mimics circulating $\mathrm{HCV}$ virions in vivo, HCVcc stock was first concentrated using the Amicon Ultra-15 device (100,000 NMWL membrane; Millipore) as described previously [11]. The concentrated virus stock $\left(1.1 \times 10^{6} \mathrm{FFU} / \mathrm{ml}\right)$ was then diluted 11-fold in normal human serum that had been heat-inactivated to achieve an infectious titer of $1.0 \times 10^{5} \mathrm{FFU} / \mathrm{ml}$. This human serum containing $\mathrm{HCV} c \mathrm{c}$ was stored at $-70^{\circ} \mathrm{C}$ in aliquots until use.

\section{$\mathrm{HCV}$ infectivity assay}

The infectious titers of virus stocks and treated viral samples were determined by FFU assay, as described previously [24], using an indirect immunofluorescence assay (IFA) for HCV NS3. In brief, $100 \mu \mathrm{l}$ of 10 -fold serially diluted samples (the dilution factors generally ranged from 1:1 to1:1000) were inoculated onto naïve Huh7-25-CD81 cells seeded in 96-well plates 1 day before infection (7000 cells/well). After $6 \mathrm{~h}$ of incubation at $37^{\circ} \mathrm{C}$, cells were refed with $100 \mu \mathrm{l}$ fresh medium. Following an additional $72 \mathrm{~h}$, cells were fixed in $4 \%$ paraformaldehyde for $30 \mathrm{~min}$ at room temperature (RT), blocked for $60 \mathrm{~min}$ in a blocking buffer (3\% BSA, 0.3\% Triton X-100, 10\% FBS in PBS), followed by incubation with a polyclonal antibody against HCV NS3 (kindly provided by Dr. Takaji Wakita) at 1:500 dilution. After 2 $h$ incubation at RT, cells were washed extensively with PBS and then incubated with an FITC-conjugated goat anti-rabbit IgG (Beijing Zhongshanjinqiao, China) at 1:100 dilution for $1 \mathrm{~h}$. Following PBS washes, the numbers of fluorescent foci (a focus is defined as a cluster of infected cells immunostained positive for NS3 antigen) per well at appropriate dilutions (generally containing 5 to 100 foci per well) were counted. The infectious titers, expressed as $\mathrm{FFU} / \mathrm{ml}$, were calculated from the average foci number of triplicate or duplicate (for samples 
derived from human serum spiked with $\mathrm{HCVcc}$ ) wells. The detection limit of the FFU assay was $10 \mathrm{FFU} / \mathrm{ml}$. For samples with infectious titers below the detection limit of the assay, the potential residual infectivity was examined as follows. Naïve Huh7-25-CD81 cells seeded in 96-well plates were inoculated with samples to be tested $(100 \mu \mathrm{l} /$ well). Inoculated cells were passaged at 3day intervals from one well into three wells at each passage (with a 1:3 split ratio) to allow growth of residual infectious virus. IFA for NS3 were performed on each cell passage. If the IFA results remained negative for three successive cell passages (up to 9 days postinoculation), the tested sample was considered to be inactivated completely.

\section{Viral stability assays}

An HCVcc stock with a titer of $2.5 \times 10^{4} \mathrm{FFU} / \mathrm{ml}$ was dispensed into $300-\mu \mathrm{l}$ aliquots in tightly capped, $1.5-\mathrm{ml}$ microcentrifuge tubes and then incubated at $37^{\circ} \mathrm{C}, \mathrm{RT}$ $\left(25 \pm 2^{\circ} \mathrm{C}\right)$, and $4^{\circ} \mathrm{C}$, respectively, and protected from light. Aliquots incubated at $37^{\circ} \mathrm{C}$ were removed every 8 $\mathrm{h}$, while those incubated at RT or $4^{\circ} \mathrm{C}$ were removed every 2 days or every 2 weeks, respectively, and stored at $-70^{\circ} \mathrm{C}$ until virus titration on Huh7-25-CD81 cells. For viral stability assays for $\mathrm{HCVcc}$ spiked in normal human serum $\left(1.0 \times 10^{5} \mathrm{FFU} / \mathrm{ml}\right)$, aliquots were incubated at RT and removed every 7 days for titration. All the time points selected in the experiments were designed based on the results of several pilot experiments.

\section{Heat treatment}

An HCVcc stock in culture medium $\left(2.5 \times 10^{4} \mathrm{FFU} / \mathrm{ml}\right)$ or concentrated HCVcc stock diluted in human serum $\left(1.0 \times 10^{5} \mathrm{FFU} / \mathrm{ml}\right)$ was dispensed into $100-\mu \mathrm{l}$ aliquots in tightly capped, $1.5-\mathrm{ml}$ microcentrifuge tubes and then incubated in water baths with temperatures of $56^{\circ} \mathrm{C}, 60^{\circ}$ $\mathrm{C}$, and $65^{\circ} \mathrm{C}$, respectively. At designated time points, aliquots were removed, transferred immediately into icewater bath to stop the effect of heat, and then subjected to FFU assay for virus titration.

\section{UVC light irradiation}

Two hundred-microliter aliquots of an HCVcc stock $\left(2.5 \times 10^{4} \mathrm{FFU} / \mathrm{ml}\right)$ or HCVcc diluted in normal human serum $\left(1.0 \times 10^{5} \mathrm{FFU} / \mathrm{ml}\right)$ were placed in 48 -well plates to give a volume depth of about $0.2 \mathrm{~cm}$ and then exposed to continuous UVC light $30 \mathrm{~cm}$ beneath the longitudinal midpoint of a UVC lamp (model: ZSZ20D, wavelength $=253.7 \mathrm{~nm}$, Beijing Haidian Konghou High Temperature Composite Material Factory, China). At the distance of $30 \mathrm{~cm}$, the radiant intensity of the UVC lamp was $450 \mu \mathrm{W} / \mathrm{cm}^{2}$ (where $\mu \mathrm{W}=10^{-6} \mathrm{~J} / \mathrm{sec}$ ), as specified by the manufacturer. After varying lengths of exposure, samples $(200 \mu \mathrm{l})$ were removed, and their residual infectivity was titrated on Huh7-25-CD81 cells immediately. Control samples were set up in parallel and incubated for the same time period but protected from UVC light.

\section{MTT cytotoxicity assay}

MTT [3-(4, 5-dimethylthiazol-2-yl)-2, 5-diphenyl tetrazolium bromide] cytotoxicity assay was carried out to determine the concentrations of aldehydes or detergents at which they were no longer cytotoxic to Huh7-25CD81 cell. Solutions of aldehydes (37\% formaldehyde and $50 \%$ glutaraldehyde) or detergents [sodium dodecyl sulfate (SDS, $0.1 \%$ ), Triton X-100 (0.2\%) or nonidet P-40 (NP-40, 0.2\%)] were diluted serially in cell culture medium, respectively (the range of concentrations for each reagent was designed based on the results of pilot experiments). The diluted reagents were then added to Huh7-25-CD81 cells seeded in 96-well plates (7000 cells/well) 1 day before. After $6 \mathrm{~h}$ of incubation at $37^{\circ} \mathrm{C}$, the treated cells were refed with $100 \mu \mathrm{l}$ of fresh culture medium to keep the exposure time to the individual reagents the same as that in HCV infectivity assay. Following an additional $72 \mathrm{~h}, 20 \mu \mathrm{l}$ of MTT solution (5 $\mathrm{mg} / \mathrm{ml}$, Sigma-Aldrich) was added to each well. After a 4-h incubation at $37^{\circ} \mathrm{C}$, the MTT solution was removed and replaced with $200 \mu \mathrm{l}$ of dimethyl sulfoxide (DMSO, Sigma-Aldrich) per well. After the formazan crystals were dissolved by agitation ( $10 \mathrm{~min}$ at RT), the absorbance of solution in each well was measured at $490 \mathrm{~nm}$ using an enzyme-linked immunosorbent assay plate reader (Bio-Rad). The percentage of cell viability was calculated as the ratio of absorbance in treated cells compared with that in untreated controls. All experiments were performed in triplicate and repeated twice.

\section{Formaldehyde and glutaraldehyde treatments}

Formaldehyde (37\%) or glutaraldehyde (50\%) solutions (Beijing Chemical Reagents Company, China) were diluted in PBS at 1:10 (formaldehyde) or 1:50 (glutaraldehyde), respectively, then added to $500-\mu$ l viral samples [HCVcc stock in cell culture medium $\left(4.1 \times 10^{4} \mathrm{FFU} /\right.$ $\mathrm{ml})$ or HCVcc-containing human serum $\left(1.0 \times 10^{5} \mathrm{FFU} /\right.$ $\mathrm{ml})$ ] to achieve a final concentration of $0.037 \%$ (formaldehyde) or $0.01 \%$ (glutaraldehyde), respectively. After different time periods at RT, treated samples were diluted 100-fold in culture medium immediately to stop the inactivation reaction, as well as to eliminate the cytotoxic effect of aldehydes in subsequent FFU assays (according to the results of the MTT assay, the presence of $0.00037 \%$ formaldehyde or $0.0001 \%$ glutaraldehyde had no appreciable effect on the viability of Huh7-25-CD81 cells). Immediately after the dilution, HCV infectivity in samples was titrated by FFU assay in Huh7-25-CD81 
cells. Samples showing negative results in FFU assay were subjected to the residual infectivity test, as described in "HCV infectivity assay" As control, PBS was substituted for the aldehydes to treat the virus stocks, which were then diluted 100-fold to infect cells in the presence of either $0.00037 \%$ formaldehyde or $0.0001 \%$ glutaraldehyde, respectively.

\section{Detergent treatments}

Solutions of $0.5 \%$ SDS $(\mathrm{w} / \mathrm{v}), 1 \%$ Triton X-100 (v/v), or $1 \% \mathrm{NP}-40(\mathrm{v} / \mathrm{v})$ (all prepared in PBS) were added to $500-\mu \mathrm{l}$ aliquots of viral samples [HCVcc stock in cell culture medium $\left(4.1 \times 10^{4} \mathrm{FFU} / \mathrm{ml}\right)$ or normal human serum containing $\left.\mathrm{HCVcc}\left(1.0 \times 10^{5} \mathrm{FFU} / \mathrm{ml}\right)\right]$ to achieve a final concentration of either $0.1 \%$ (SDS) or $0.2 \%$ (Triton X-100 and NP-40). After a gentle mixing (within 1 min), treated samples were diluted 100-fold (SDS-treated samples) or 400-fold (Triton X-100- or NP-40-treated samples) immediately in culture medium to negate the cytotoxic effect of detergents (based on the MTT assay results, the presence of $0.001 \%$ SDS, $0.0005 \%$ Triton X-100, or $0.0005 \%$ NP-40 had no demonstrable effect on the viability of Huh7-25-CD81 cells), then subjected to FFU assay. Samples with negative FFU assay results were examined for residual infectivity. As control, PBS was used in place of the detergents to treat the virus stocks, which were subsequently diluted either 100- or 400-fold to infect the Huh7-25-CD81 cells in the presence of $0.001 \%$ SDS, $0.0005 \%$ Triton X-100, or $0.0005 \%$ NP-40, respectively.

To assess the ability of detergents to disrupt intracellular HCV, JFH-1 infected Huh7-25-CD81 cell monolayers grown in 24-well plates (approximately $100 \%$ of cells stained positive for NS3 at the time of cell lysis as examined by IFA) were detached by trypsin/EDTA and washed extensively with PBS, and cell pellets were resuspended in $50 \mu \mathrm{l}$ PBS containing $0.1 \%$ SDS, or $0.2 \%$ Triton X-100, or $0.2 \% \mathrm{NP}-40$, respectively (each detergent was disruptive to cells at these concentrations as visualized by microscopy). After centrifugation, the supernatants of cell lysates were diluted 100-fold (SDS-lysed samples) or 400-fold (Triton X-100- or NP-40-lysed samples) in culture medium for infectivity assays. IFA of HCV NS3 was performed on inoculated cells for three consecutive cell passages. As control, infected cells washed extensively with PBS were pelleted and resuspended in $50 \mu \mathrm{l}$ PBS and lysed by three cycles of freezing and thawing $\left(-70^{\circ} \mathrm{C}\right.$ to $\left.37^{\circ} \mathrm{C}\right)$, and the infectivity of supernatants was titrated on Huh7-25-CD81 cells.

\section{Acknowledgements}

We are grateful to Dr. Takaji Wakita (National Institute of Infectious Diseases, Tokyo, Japan) for providing JFH-1 virus, Huh7-25-CD81 cell line, and HCV NS3 polyclonal antibody. We also thank Dr. Teng Ma (Peking University
Health Science Center, Beijing, China) for technical assistance and Dr. David Armbruster (University of Tennessee Health Science Center) for carefully reading the manuscript. This work was supported by the Major Science and Technology Special Project of China Eleventh Five-year Plan (2008ZX10002013), and the financial grants from the National Key Science and from the National Institute of Allergy and Infectious Diseases (R01-Al069285).

\section{Author details}

${ }^{1}$ Department of Microbiology, Peking University Health Science Center, Beijing 100191, China. ${ }^{2}$ Department of Molecular Sciences, University of Tennessee Health Science Center, Memphis, Tennessee 38163, USA.

\section{Authors' contributions}

$\mathrm{HZ}$ and $\mathrm{KL}$ conceived the study and designed the experiments. HSS, JL, SS and LY carried out the experimental work. HSS, HZ and KL wrote the paper. All Authors have read and approved the final manuscript.

\section{Competing interests}

The authors declare that they have no competing interests.

Received: 3 November 2009

Accepted: 18 February 2010 Published: 18 February 2010

\section{References}

1. Lemon SM, Walker C, Alter MJ, Yi M, Knipe D, Howley P, Griffin DE, Martin MA, Lamb RA, Roizman B, Straus SE: Hepatitis C viruses. Fields Virology Philadelphia: Lippincott Williams \& WilkinsKnipe DM, Howley PM , Fifth 2007, 1253-1304.

2. Webster DP, Klenerman P, Collier J, Jeffery KJ: Development of novel treatments for hepatitis C. Lancet Infect Dis 2009, 9:108-117.

3. Alter MJ: The detection, transmission, and outcome of hepatitis $C$ virus infection. Infect Agents Dis 1993, 2:155-166.

4. Kamili S, Krawczynski K, McCaustland K, Li X, Alter MJ: Infectivity of hepatitis $C$ virus in plasma after drying and storing at room temperature. Infect Control Hosp Epidemiol 2007, 28:519-524.

5. Hilfenhaus J, Groner A, Nowak T, Weimer T: Analysis of human plasma products: polymerase chain reaction does not discriminate between live and inactivated viruses. Transfusion 1997, 37:935-940.

6. Sattar SA, Tetro J, Springthorpe VS, Giulivi A: Preventing the spread of hepatitis B and $C$ viruses: where are germicides relevant?. Am J Infect Control 2001, 29:187-197.

7. Azar Daryany MK, Hosseini SM, Raie M, Fakharie J, Zareh A: Study on continuous ( $254 \mathrm{~nm}$ ) and pulsed UV (266 and $355 \mathrm{~nm}$ ) lights on BVD virus inactivation and its effects on biological properties of fetal bovine serum. J Photochem Photobiol B 2009, 94:120-124.

8. Remington KM, Trejo SR, Buczynski G, Li H, Osheroff WP, Brown JP, Renfrow H, Reynolds R, Pifat DY: Inactivation of West Nile virus, vaccinia virus and viral surrogates for relevant and emergent viral pathogens in plasma-derived products. Vox Sang 2004, 87:10-18.

9. Cai Z, Zhang C, Chang KS, Jiang J, Ahn BC, Wakita T, Liang TJ, Luo G: Robust production of infectious hepatitis $\mathrm{C}$ virus (HCV) from stably HCV cDNA-transfected human hepatoma cells. J Virol 2005, 79:13963-13973.

10. Lindenbach BD, Evans MJ, Syder AJ, Wolk B, Tellinghuisen TL, Liu CC, Maruyama T, Hynes RO, Burton DR, McKeating JA, Rice CM: Complete replication of hepatitis $C$ virus in cell culture. Science 2005, 309:623-626.

11. Wakita T, Pietschmann T, Kato T, Date T, Miyamoto M, Zhao Z, Murthy K, Habermann A, Krausslich HG, Mizokami M, Bartenschlager R, Liang TJ: Production of infectious hepatitis $C$ virus in tissue culture from a cloned viral genome. Nat Med 2005, 11:791-796.

12. Zhong J, Gastaminza P, Cheng G, Kapadia S, Kato T, Burton DR, Wieland SF, Uprichard SL, Wakita T, Chisari FV: Robust hepatitis C virus infection in vitro. Proc Natl Acad Sci USA 2005, 102:9294-9299.

13. Akazawa D, Date T, Morikawa K, Murayama A, Miyamoto M, Kaga M, Barth H, Baumert TF, Dubuisson J, Wakita T: CD81 expression is important for the permissiveness of Huh7 cell clones for heterogeneous hepatitis C virus infection. J Virol 2007, 81:5036-5045.

14. Burnouf $T$, Radosevich M: Reducing the risk of infection from plasma products: specific preventative strategies. Blood Rev 2000, 14:94-110.

15. Schlegel A, Immelmann A, Kempf C: Virus inactivation of plasma-derived proteins by pasteurization in the presence of guanidine hydrochloride. Transfusion 2001, 41:382-389. 
16. Charm SE, Landau S, Williams B, Horowitz B, Prince AM, Pascual D: Hightemperature short-time heat inactivation of HIV and other viruses in human blood plasma. Vox Sang 1992, 62:12-20.

17. Darnell ME, Subbarao K, Feinstone SM, Taylor DR: Inactivation of the coronavirus that induces severe acute respiratory syndrome, SARS-CoV. J Virol Methods 2004, 121:85-91.

18. Perdiz D, Grof P, Mezzina M, Nikaido O, Moustacchi E, Sage E: Distribution and repair of bipyrimidine photoproducts in solar UV-irradiated mammalian cells. Possible role of Dewar photoproducts in solar mutagenesis. J Biol Chem 2000, 275:26732-26742.

19. Fraenkel-Conrat $\mathrm{H}$ : Reaction of nucleic acid with formaldehyde. Biochim Biophys Acta 1954, 15:307-309.

20. Jiang W, Schwendeman SP: Formaldehyde-mediated aggregation of protein antigens: comparison of untreated and formalinized model antigens. Biotechnol Bioeng 2000, 70:507-517.

21. Payan C, Cottin J, Lemarie C, Ramont C: Inactivation of hepatitis B virus in plasma by hospital in-use chemical disinfectants assessed by a modified HepG2 cell culture. J Hosp Infect 2001, 47:282-287.

22. Roberts PL, Dunkerley C: Effect of manufacturing process parameters on virus inactivation by solvent-detergent treatment in a high-purity factor IX concentrate. Vox Sang 2003, 84:170-175.

23. Kim IS, Choi YW, Woo HS, Chang CE, Lee S: Solvent/detergent inactivation and chromatographic removal of human immunodeficiency virus during the manufacturing of a high purity antihemophilic factor VIII concentrate. J Microbio/ 2000, 38:187-191.

24. Yi M, Ma Y, Yates J, Lemon SM: Compensatory mutations in E1, p7, NS2, and NS3 enhance yields of cell culture-infectious intergenotypic chimeric hepatitis C virus. J Virol 2007, 81:629-638.

doi:10.1186/1743-422X-7-40

Cite this article as: Song et al.: Thermal stability and inactivation of hepatitis C virus grown in cell culture. Virology Journal 2010 7:40.

\section{Submit your next manuscript to BioMed Central and take full advantage of:}

- Convenient online submission

- Thorough peer review

- No space constraints or color figure charges

- Immediate publication on acceptance

- Inclusion in PubMed, CAS, Scopus and Google Scholar

- Research which is freely available for redistribution

Submit your manuscript at www.biomedcentral.com/submit 